\title{
The Vasoactivity of the Fetal Lamb Ductus Arteriosus Studied in Utero
}

\author{
WILLIAM F. FRIEDMAN, ${ }^{(34)}$ MORTON P. PRINTZ, STANLEY E. KIRKPATRICK, AND \\ ED J. HOSKINS
}

\begin{abstract}
Division of Pediatric Cardiology, Department of Pediatrics, University of California, Los Angeles, School of Medicine, UCLA Center for the Health Sciences; and the Department of Medicine, University of California, San Diego, School of Medicine, La Jolla, California, USA
\end{abstract}

\begin{abstract}
Summary
The ductus arteriosus of the undisturbed fetal lamb was studied chronically by techniques that allowed direct serial measurements of the calibre of the fetal channel. When the direct actions were studied of vasoactive agents on the ductus arteriosus, prostaglandins did not dilate the vessel beyond its resting dimensions. The cyclooxygenase inhibitor, indomethacin, was a potent vasoconstrictor with a plateau of the dose-effect relationship occurring at $0.2 \mathrm{mg} / \mathrm{kg}$. Fetuses of $95-98$ days gestational age were equally sensitive to indomethacin when compared to animals near term. Although the prostaglandins, $\mathrm{PGE}_{1}, \mathrm{PGE}_{2} \mathrm{PGF}_{2 \alpha}, \mathrm{PGH}_{2}, \mathrm{PGI}_{2}$ and $\mathbf{P G G}_{2}$, had no direct effect on the ductus arteriosus, $\mathbf{P G E}_{1}$, $\mathbf{P G E}_{2}, \mathbf{P G H}_{2}$ and $\mathbf{P G I}_{2}$ reversed the vasoconstrictor action of indomethacin. Autonomic nervous system mediators and blockers, i.e., acetylcholine, atropine, norepinephrine, propranolol, phentolamine and methoxamine, had neither direct effects on the ductus arteriosus nor any influence on indomethacin-induced vasoconstriction. The same was true of angiotensin 1, angiotensin 2, blockade of conversion of angiotensin 1 to 2 , serotonin, methysergide, aminophylline, adenosine, and dibutyryl cyclic AMP. Imidazole, a blocker of thromboxane synthase, had no direct effect on the ductus arteriosus, but reduced significantly the magnitude of the indomethacin constrictor action.

The major finding of this investigation was the exquisite sensitivity of the ductus arteriosus to manipulations of the prostaglandin environment. The results suggest that both locally generated prostaglandins, as well as prostanoids in the circulation, may be involved in ductal patency and closure. A high degree of control is likely of the circulation of the ductus arteriosus and constriction of the fetal channel is probably the result of an active process.
\end{abstract}

Evidence has emerged from our own (15-18) and other laboratories $(5,8-11,20)$ indicating that prostaglandins may play a key role in the dramatic events that occur in the transition from fetal to adult circulatory pathways; in particular, in controlling the circulation of the ductus arteriosus. The latter vessel is a unique structure because its patency after birth may, on the one hand, result in cardiac decompensation (14), but on the other hand, may provide the only life-sustaining conduit to preserve systemic or pulmonary blood flow in the presence of associated cardiac malformations (21). Previous studies of the vasomotor activity of the ductus arteriosus employed isolated strips or rings of the vessel, often exposed transiently or throughout "in vitro life" to conditions of $\mathrm{P}_{2}$, light and temperature that bear little relation to in utero conditions and that therefore may have altered the vessel's pharmacologic responsiveness. Accordingly, the present in vivo studies were performed in the chronically instrumented, undisturbed fetal lamb. Techniques were developed that allowed, for the first time, direct observations of ductal calibre in situ. These investigations were designed to evaluate the effects of prostaglandins and inhibitors of endogenous prostaglandin synthesis on the hemodynamics and dimensions of the ductus arteriosus, as well as the interaction between these stimuli, other vasoactive agents, and the autonomic nervous system.

\section{MATERIALS AND METHODS}

Surgical and technical modifications of the sonocardiometry methods previously reported from our laboratory $(22,24)$ were utilized to study the intact fetal lamb ductus. One hundred and sixty-six experiments were performed on 42 time-dated pregnant ewes of mixed western breeds. The ewes were operated upon at known gestational ages of 95-124 days (term $=148$ days). Preoperative medication consisted of intramuscular meperidine (100 $\mathrm{mg}$ ) and chlorpromazine $(50 \mathrm{mg})$ for sedation and atropine (0.4 $\mathrm{mg}$ ) for minimizing secretions. Hysterotomy was performed under spinal anesthesia ( $3 \mathrm{ml}$ of $1 \%$ tetracaine hydrochloride) and sedation of the ewe and fetus were maintained during the operation by giving $60-180 \mathrm{mg}$ of sodium pentabarbitol intravenously to the ewe. Local anesthesia of the fetus was obtained with $1 \%$ lidocaine. The fetal head and neck were exteriorized and polyvinyl catheters were placed in the carotid artery and jugular vein. The arterial catheter provided measurement of ascending aortic blood pressure and the jugular venous catheter was placed in the superior vena cava for infusion of pharmacologic agents. After replacing the fetal head, a left thoracotomy was performed exposing the main pulmonary artery, ductus arteriosus and descending aorta. Polyvinyl catheters were placed in the descending aorta and proximal main pulmonary artery and each was secured with a pursestring suture. The patent ductus arteriosus was exposed along its entirety and $2 \mathrm{~mm}$ piezoelectric crystals were glued (Eastman 910) to the adventitial tissue of the patent ductus arteriosus directly opposite one another at the midpoint of the length of the ductus. The wires and catheters were passed through the fetal skin, uterus and ewe's flank and coiled into a cloth pouch sewn to the mother's left flank. Postoperatively, the ewes were housed in separate stalls and fed water, pellets, and alfalfa. Intramuscular injections of penicillin $(1,000,000$ units) and streptomycin $(0.5 \mathrm{~g})$ were administered daily for 10 days after surgery. Every other postoperative day, each animal was brought to the laboratory and oriented to the area and personnel. Catheters were flushed with heparinized saline (4 USP units $/ \mathrm{ml} 5 \%$ dextrose in water). Fetuses were allowed a 2-7 day recovery period before pharmacologic intervention. All signals were recorded on a Clevite-Brush oscillographic recorder. Ascending aorta, descending aorta and proximal main pulmonary artery catheters were connected to Statham P23 DB pressure gauges. Zero reference was obtained by positioning the pressure gauges opposite the fetal position so that intrauterine pressure equaled atmospheric pressure.

The direct determinations of ductus arteriosus dimensions and the estimated wall thickness $(1 \mathrm{~mm})$ of the ductus arteriosus, based on 30 postsacrificed specimens, were used to calculate the change in the internal cross-sectional area of the ductus arteriosus. The equations employed were:

$$
A_{1}=\uparrow\left(d_{1}-2 t_{1}\right)^{2} / 4 \text { and } A_{2}=\llbracket / 4\left[d_{2}{ }^{2}-4 t_{1}\left(d_{1}-t_{1}\right)\right]
$$


where $\mathrm{A}=$ internal diameter, $\mathrm{d}=$ external diameter, $\mathrm{t}=$ wall thickness. Subscripts 1 and 2 refer to pre- and postintervention values. The percentage change in cross-sectional area was calculated as $\frac{A_{1}-A_{2}}{A_{1}} \times 100 \%$. All values reported are expressed as means \pm S.E.M. and have been compared, when appropriate, using the Student $t$ test.

In order to ascertain if the ductus arteriosus piezoelectric dimension crystals were placed at a site allowing detection of maximum constriction of the ductus arteriosus, five chronically instrumented fetal lambs underwent selective injections of contrast material (Hypaque $\mathrm{M}-75 \%, 1 \mathrm{ml} / \mathrm{kg}$, and normal saline, $1 \mathrm{ml} / \mathrm{kg}$ ) into the fetal main pulmonary artery with cineangiographic monitoring.

Experiments were designed to study the direct actions of vasoactive agents on the ductus arteriosus, as well as the influence of the prior administration of these agents on indomethacin or other prostaglandin synthetase inhibitor responses, and, lastly, the action of these agents on the ductus arteriosus already constricted by indomethacin. A basic seven-step protocol was constructed for each vasoactive agent, which was modified according to specific results. Steps 1 through 4 were identical. In step 5 the specific agent was given alone, before, and/or after inhibition of prostaglandin synthesis. Step 1: Each animal was studied while standing quietly in a mobile cage with food and water available at the head of the cage. Every other day during the postoperative recovery period and before the experimental stimulus the animals were brought to the laboratory to flush catheters and to familiarize them with the study environment. Step 2: The maternal femoral artery and fetal main pulmonary artery, ascending aorta, descending aorta, and superior vena caval catheters were opened and flushed with heparinized saline. Step 3: Control blood samples were collected from the ewe's femoral artery and fetal ascending aorta to evaluate $\mathrm{pH}, \mathrm{PO}_{2}$, and $\mathrm{PCO}_{2}$. These blood samples were heparinized and analyzed immediately for $\mathrm{pH}$ and blood gases on an Instrumentation Laboratory analyzer, after correction for temperature and barometric pressure. Step 4: Fetal arterial catheters were connected to Statham P23 dB pressure transducers and the ultrasonic ductus arteriosus crystal wires connected to the dimension gauge system and calibrated with a signal of known transit time. Step 5: After obtaining baseline pressures, heart rate, ductus arteriosus dimensions, and blood gas samples, a vasoactive agent was infused into a pre-selected fetal catheter site (Table 1). The latter was invariably the superior vena cava, although certain perturbations, discussed below, used additional sites of drug infusion. Fetal weights forming the basis for dosimetry were calculated from known gestational ages. When a single drug was infused to determine its direct action on the ductus, the animal in the control period was not under the influence of any vasoactive agent administered earlier. The ability of a substance to dilate the ductus arteriosus was tested after the vessel was constricted by indomethacin. Step 6: Fetal blood pressures and ductus arteriosus dimensions were recorded continuously until maximum and/or steady state ductus responses were observed. Step 7: Depending upon the response of the ductus arteriosus to a single pharmacologic stimulus, a second perturbation may have been employed.

All drugs were prepared freshly immediately before fetal experimentation. SQ20881, angiotensin converting enzyme inhibitor, was supplied graciously by Dr. Zola Horovitz of Squibb. Dr. John Pike of the Upjohn Co. kindly supplied all of the prostaglandins. Dr. Morton Rosenberg, of Merck, Sharp \& Dohme kindly provided lyophilized indomethacin. All prostaglandins (except $\mathrm{PGI}_{2}$ ) were dissolved first in ethanol and diluted subsequently with saline for injection. $\mathbf{P G I _ { 2 }}$ was dissolved in $10 \mathrm{mM}$ sodium bicarbonate buffer $(\mathrm{pH} \mathrm{9)}$ and diluted with saline immediately before injection.

\section{RESULTS}

PROSTAGLANDIN SYNTHETASE INHIBITORS

Indomethacin. The effects of inhibiting endogenous prostaglandin synthesis with indomethacin on the contractile behavior in utero of the fetal ductus arteriosus was studied in 61 experiments on 30 fetal lambs between the gestational ages of 95-148 days, and 1-24 days postoperatively. Indomethacin was given in doses ranging from $0.001-1.00 \mathrm{mg} / \mathrm{kg}$, which allowed construction of a dose-effect relationship (Fig. 1). Significant constriction of the fetal channel began at doses as low as $0.01 \mathrm{mg} / \mathrm{kg}$; the plateau of the dose-response curve occurred at dosage levels of approximately $0.2 \mathrm{mg} / \mathrm{kg}$. Over the gestational age range studied, no age-related differences were observed in the response of the ductus arteriosus to indomethacin; thus, the values for ductal constriction in fetuses of 95-98 days gestational age were the same as those for older animals, and conformed to the dose-response curve. The time course of the response to indomethacin was not evaluated completely, nor were pharmacokinetic studies undertaken. We did

Table 1

\begin{tabular}{|c|c|c|c|}
\hline$N^{1}$ & Pharmacologic agents & Dose & $\begin{array}{l}\text { Effect on } \\
\text { ductus }\end{array}$ \\
\hline & $\begin{array}{l}\text { Prostaglandin synthetase in- } \\
\text { hibitors }\end{array}$ & & \\
\hline 61 & Indomethacin & $\begin{array}{l}0.001-1.0 \mathrm{mg} / \\
\mathrm{kg}\end{array}$ & $\begin{array}{l}\text { Constricts } \\
\text { Dilates }\end{array}$ \\
\hline \multirow[t]{2}{*}{18} & Imidazole & $\begin{array}{l}2.0-4.0 \mathrm{mg} / \mathrm{kg} / \\
\min \end{array}$ & \\
\hline & Prostaglandins & $\begin{array}{l}0.1-1.0 \mu \mathrm{g} / \mathrm{kg} / \\
\min \end{array}$ & Dilates \\
\hline 63 & PGE1 & $\begin{array}{l}0.1-1.0 \mu \mathrm{g} / \mathrm{kg} / \\
\quad \min \end{array}$ & Dilates \\
\hline 2 & PGE2 & $\begin{array}{l}0.1-1.0 \mu \mathrm{g} / \mathrm{kg} / \\
\min \end{array}$ & 0 \\
\hline 2 & PGF2 alpha & $2.0 \mu \mathrm{g} / \mathrm{kg} / \mathrm{min}$ & Dilates \\
\hline 2 & $\mathrm{PGH} 2$ & $\begin{array}{l}1.0-100.0 \mu \mathrm{g} / \mathrm{kg} / \\
\min \end{array}$ & 0 \\
\hline \multirow[t]{2}{*}{25} & PGI2 & $2.5-120.0 \mu \mathrm{g} / \mathrm{kg}$ & 0 \\
\hline & & $\begin{array}{l}510.0-850.0 \mu \mathrm{g} / \\
\mathrm{kg}\end{array}$ & Dilates \\
\hline \multirow[t]{2}{*}{3} & PGG2 ether analogue & $\begin{array}{l}0.25-25.0 \mu \mathrm{g} / \mathrm{kg} / \\
\min \end{array}$ & 0 \\
\hline & $\begin{array}{l}\text { Autonomic nervous system } \\
\text { mediators and blockers }\end{array}$ & & \\
\hline 3 & Acetylcholine & $\begin{array}{l}0.01-1.0 \mu \mathrm{g} / \mathrm{kg} / \\
\min \end{array}$ & 0 \\
\hline 3 & Atropine & $0.2 \mathrm{mg} / \mathrm{kg}$ & 0 \\
\hline 2 & Norepinephrine & $\begin{array}{l}0.1-1.0 \mu \mathrm{g} / \mathrm{kg} / \\
\min \end{array}$ & 0 \\
\hline 2 & Propranolol & $1.0 \mathrm{mg} / \mathrm{kg}$ & 0 \\
\hline 5 & Phentolamine & $0.1 \mathrm{mg} / \mathrm{kg}$ & 0 \\
\hline \multirow[t]{2}{*}{2} & Methoxamine & $50.0 \mu \mathrm{g} / \mathrm{kg} / \mathrm{min}$ & 0 \\
\hline & $\begin{array}{l}\text { Reno-vascular and tryptami- } \\
\text { nergic agents }\end{array}$ & & \\
\hline 3 & Angiotensin 1 & $\begin{array}{l}50.0-100.0 \mu \mathrm{g} / \\
\mathrm{kg} / \mathrm{min}\end{array}$ & 0 \\
\hline 3 & Angiotensin 2 & $\begin{array}{l}50.0-100.0 \mu \mathrm{g} / \\
\mathrm{kg} / \mathrm{min}\end{array}$ & 0 \\
\hline \multirow[t]{2}{*}{4} & $\begin{array}{l}\text { Angiotensin } 1 \text { converting } \\
\text { enzyme blocker }\end{array}$ & $\begin{array}{l}10.0-250.0 \mu \mathrm{g} / \\
\mathrm{kg} / \mathrm{min}\end{array}$ & 0 \\
\hline & $(\mathrm{SQ}-20881)$ & $250.0 \mu \mathrm{g} / \mathrm{kg}$ & 0 \\
\hline 3 & Serotonin & $\begin{array}{l}100.0-300.0 \mu \mathrm{g} / \\
\mathrm{kg} / \mathrm{min}\end{array}$ & 0 \\
\hline 3 & $\begin{array}{l}\text { Methysergide } \\
\text { Agents affecting cyclic nu- } \\
\text { cleotides }\end{array}$ & $20.0-100.0 \mu \mathrm{g} / \mathrm{kg}$ & 0 \\
\hline 2 & Aminophylline & $\begin{array}{l}14.0,28.0 \mu \mathrm{g} / \mathrm{kg} / \\
\min \end{array}$ & 0 \\
\hline 2 & Adenosine & $2.0 \mathrm{mg} / \mathrm{kg} / \mathrm{min}$ & 0 \\
\hline 4 & Dibutyryl Cyclic-AMP & $\begin{array}{l}0.4-4.0 \mathrm{mg} / \mathrm{kg} / \\
\min \end{array}$ & 0 \\
\hline
\end{tabular}

${ }^{1} \mathrm{~N}$, number of experiments. Ability to dilate was tested on the indomethacin constricted ductus. 
note, however, that the time from infusion to maximal constriction averaged $44 \pm 3 \mathrm{~min}$, with an initial increase in pulmonary arterial pressure and heart rate within the first $3 \mathrm{~min}$ after infusion. The control heart rate averaged $177 \pm 3$ beats/min whereas at maximum constriction following indomethacin it was $183 \pm 4 / \mathrm{min}(P$ $=\mathrm{NS})$. Indomethacin-induced constriction of the ductus arteriosus was always reversed completely and within 3-10 min by infusion of $\mathrm{PGE}_{1}(0.1 \mu \mathrm{g} / \mathrm{kg} / \mathrm{min})$. $\mathrm{PGE}_{1}$ reversal of ductus arteriosus constriction did not change heart rate significantly $(189 \pm 10$ beats/min).

Indomethacin caused a significant increase in systolic, but not diastolic, main pulmonary arterial pressure; $\mathrm{PGE}_{1}$ returned pulmonary systolic pressures to control values [control $=65 \pm 1 / 42$ \pm 1 torr; indomethacin $71 \pm 1 / 44 \pm 1$ torr $(P<0.001$, systolic $/ \mathrm{P}$ $=\mathrm{NS}$, diastolic); $\left.\mathrm{PGE}_{1} 65 \pm 3 / 44 \pm 2\right]$. The indomethacin-PGE experimental sequence of administration caused no significant changes in ascending aortic blood pressure (control $=60 \pm 1 / 42$ \pm 1 torr; indomethacin $61 \pm 1 / 43 \pm 1 ; \mathrm{PGE}_{1}=64 \pm 4 / 40 \pm 4$ ), or in descending aortic pressures (control $=59 \pm 1 / 42 \pm 1$ torr; indomethacin $60 \pm 1 / 44 \pm 1 ; \mathrm{PGE}_{1} 62 \pm 3 / 45 \pm 2$ ).

In the control, resting state main pulmonary artery systolic pressures slightly exceeded descending aortic systolic pressure (Fig. 2). Constriction of the ductus arteriosus with indomethacin

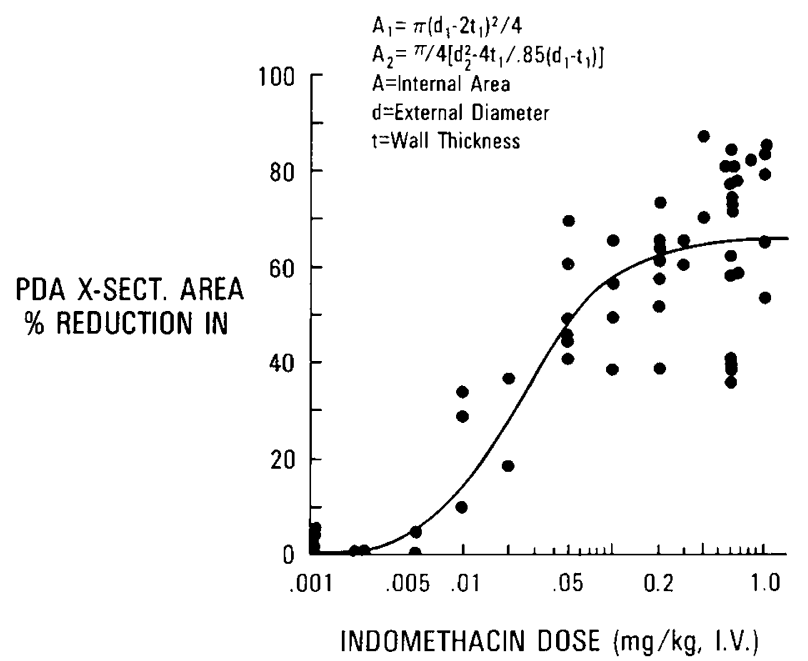

Fig. 1. Dose-effect relationship between indomethacin and the percent reduction in patent ductus arteriosus cross-sectional area. The formula for calculating the latter is described at the top and in the text. Initial wall thickness was $1.0 \mathrm{~mm}$.

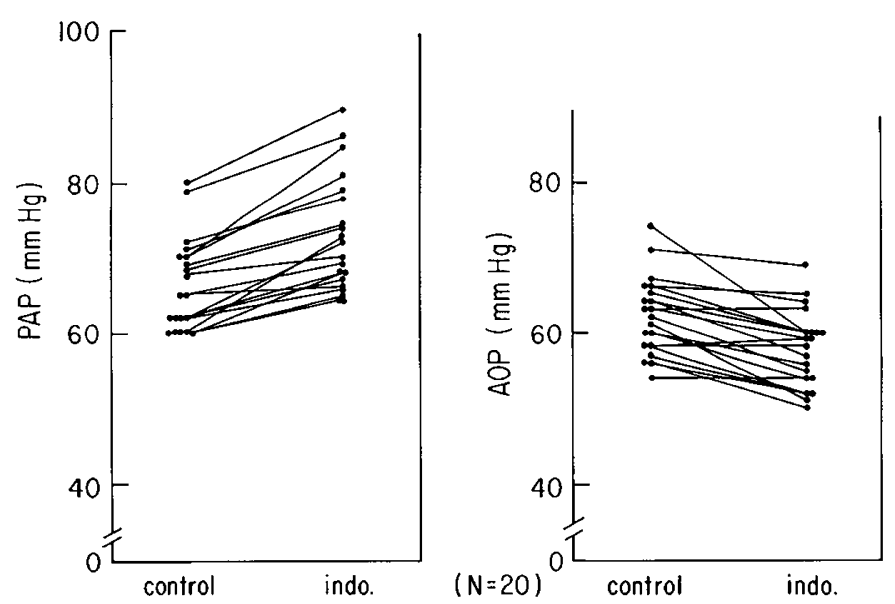

Fig. 2. Main pulmonary artery systolic $(P A P)$ and aortic systolic $(A O P)$ blood pressures $(\mathrm{mm} \mathrm{Hg})$ in the fetal lamb before (control) and after indomethacin-(indo.)-induced constriction of the ductus arteriosus. almost doubled the main pulmonary artery-aortic pressure difference $(6.0 \pm 1$ torr to $11.0 \pm 1$ torr, $P>0.005)$ (Fig. 2). After $P_{1} E_{1}$, the pressure difference between the main pulmonary artery and aorta diminished to $2.0 \pm 1$ torr $(P=\mathrm{NS}$ when compared to control pressure; $P>0.001$ when compared to indomethacin pressure). A positive correlation was found between ductal constriction and the absolute pulmonary artery-aortic pressure difference $(r=0.68, P<0.001)$, although measurements of pressure differences alone were less reliable than assessment of changes in ductus arteriosus dimensions, particularly with mild degrees of constriction of the blood vessel (22).

In calculating the change in ductus cross-sectional area in order to construct the dose-response relation between ductus constriction and indomethacin dose, we assumed that ductal constriction was not accompanied by substantial changes in the length of the vessel. Fetal angiographic studies performed during indomethacin constriction indicated that the ductus arteriosus shortened 3-10\% during its constriction; moreover, and most importantly, these angiographic studies illustrated that the point of maximum constriction of the ductus arteriosus was not at the midpoint of the vascular channel, where the piezoelectric crystals were monitoring dimension changes, but, rather, at the aortic end of the ductus arteriosus (Fig. 3). It should be recognized that an underestimation exists in our presentation of the magnitude of ductal constriction in response to indomethacin. We propose that the underestimation would be less with mild constriction, i.e., at low doses of indomethacin, and greatest with substantial constriction, i.e., at high dose levels of the drug.

Imidazole. The effects of imidazole were studied in 18 experiments on seven fetal lambs whose gestational age ranged from 115-142 days and who were 6-20 days postoperative. At the doses employed (Table 1), imidazole appeared to have no direct effect on ductus arteriosus calibre, or pulmonary arterial or aortic blood pressures; however, constant infusions of imidazole at 2 and $4 \mathrm{mg}$ / $\mathrm{kg} / \mathrm{min}$ blunted the ductal constriction induced by high doses of indomethacin $(0.6 \mathrm{mg} / \mathrm{kg})$ (Fig. 4).

Figure 4 illustrates the magnitude and dose relation of the imidazole blockade of indomethacin-induced ductal constriction. In the absence of imidazole, indomethacin caused an average reduction in the cross-sectional area of the ductus arteriosus of 56 $\pm 4 \%$. Concurrent infusion of $2 \mathrm{mg} / \mathrm{kg} / \mathrm{min}$ imidazole lessened the indomethacin constrictor response to $27 \pm 4 \%(P<0.001)$, whereas with an imidazole infusion rate of $4 \mathrm{mg} / \mathrm{kg} / \mathrm{min}$, the indomethacin constriction was reduced to $11 \pm 6 \%(P<0.001$, when compared to the lower imidazole dose). No significant changes in heart rate were associated with the administration of imidazole alone or with the combination of imidazole-indomethacin. But pulmonary and systemic blood pressure responses reflected the alterations in the calibre of the ductus arteriosus; thus, when infusion of the lesser dose of imidazole $(2 \mathrm{mg} / \mathrm{kg} / \mathrm{min})$ accompanied indomethacin administration, main pulmonary artery pressure increased from $68 \pm 1 / 44 \pm 1$ torr to $77 \pm 1 / 53 \pm 2$ $(P<0.005$ systolic $/ P<0.05$ diastolic $)$. A similar elevation in main pulmonary arterial pressure was noted at the higher imidazole dose $(4 \mathrm{mg} / \mathrm{kg} / \mathrm{min})$ from $64 \pm 11 / 44 \pm 7$ torr to $72 \pm 2 / 48$ \pm 2 torr. Ascending and descending aortic pressures did not change significantly with these perturbations.

The effect of imidazole on indomethacin-induced constriction was transient. Administration of imidazole $(4.0 \mathrm{mg} / \mathrm{kg} / \mathrm{min})$ after indomethacin promptly reversed ductal constriction within 6 min. But within $30 \mathrm{~min}$ after imidazole, ductal patency had returned to its pre-imidazole, post-indomethacin level.

Prostaglandins $E_{1}, E_{2}, F_{2 \alpha}, G_{2}, H_{2}$, and $I_{2}$. This group of vasoactive agents was evaluated in a total of 55 experiments in 15 fetal lambs, 1-26 days postoperative, with gestational ages ranging from 114-142 days. When administered directly to the resting fetus in the doses employed (Table 1), none of these prostaglandins significantly influenced heart rate, blood pressure, or ductus arteriosus dimensions. But when the ductus arteriosus was already constricted with any dose of indomethacin, $\mathrm{PGE}_{1}, \mathrm{PGE}_{2}, \mathrm{PGI}_{2}$ (Fig. 5), and the ether analogue of $\mathrm{PGH}_{2}$ (Fig. 6) promptly dilated the ductus arteriosus to control levels. In contrast, neither $\mathrm{PGF}_{2 \alpha}$ 


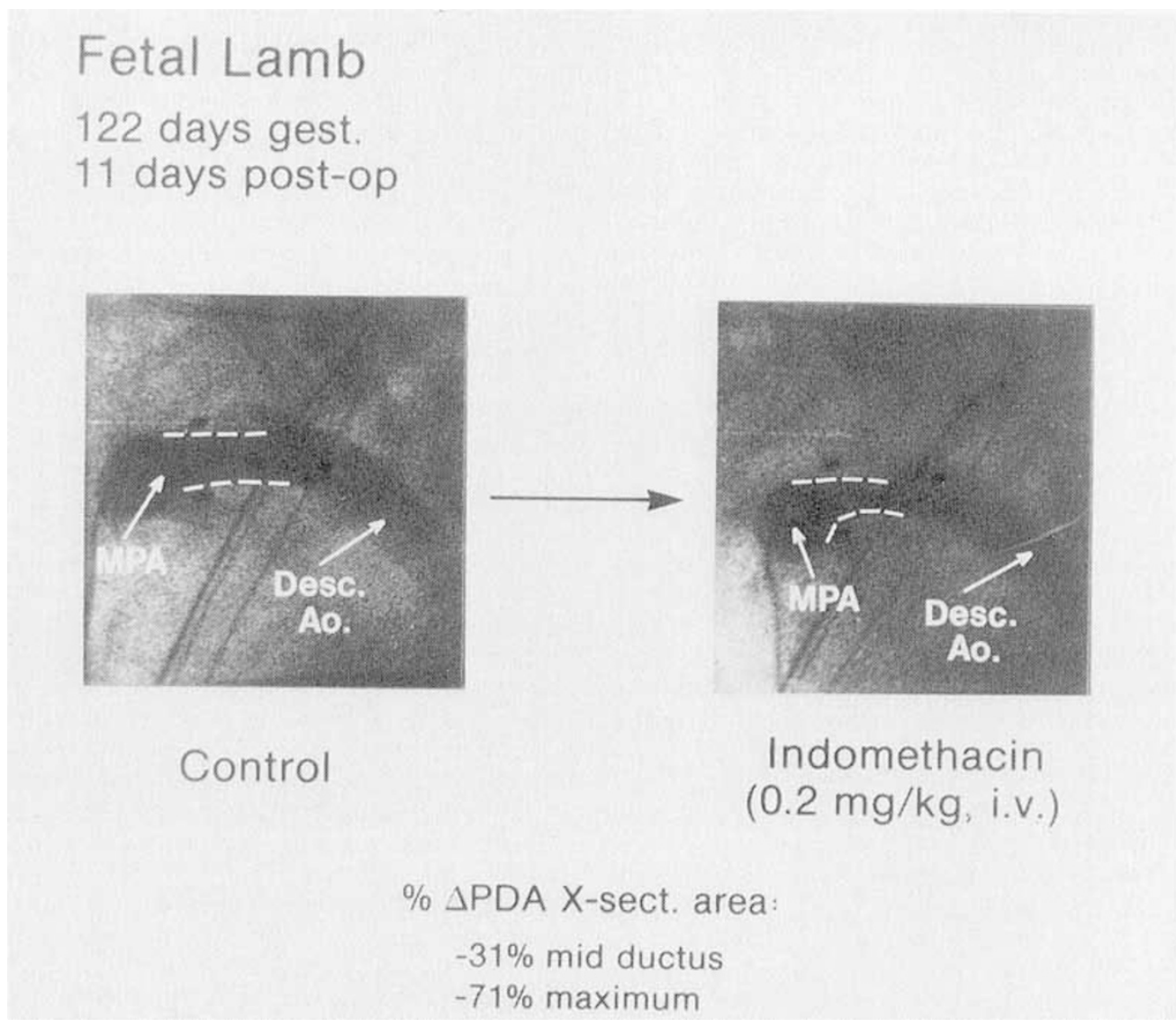

Fig. 3. Two selected cineangiographic views of the fetal ductus arteriosus after injection of contrast material into the main pulmonary artery. PDA (outlined in white) shown before (control) and $30 \mathrm{~min}$ after indomethacin $(0.2 \mathrm{mg} / \mathrm{kg}$, i.v.). Note that at midductus (location of sonomicrometer crystals) constriction was $31 \%$, whereas maximum constriction (71\%) occurred at the aortic end of the fetal channel. MPA, main pulmonary artery; Desc. Ao., descending aorta; \% $\triangle \mathrm{PDA} X$-sect. area, \% change in PDA cross-sectional area.

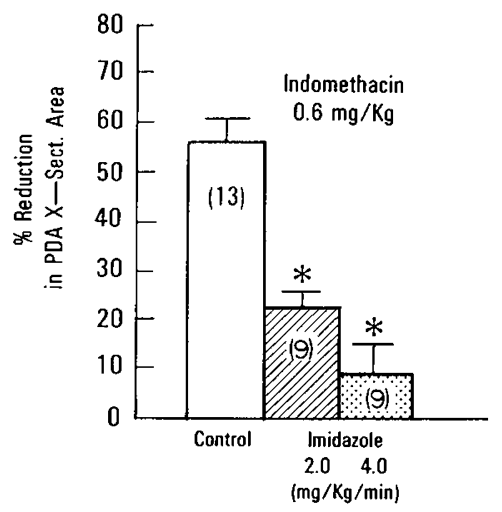

Fig. 4. Imidazole antagonism of indomethacin induced constriction of the ductus arteriosus. Control bar is the response of patent ductus arteriosus to indomethacin $(0.6 \mathrm{mg} / \mathrm{kg}$, i.v. $)$. The imidazole bars are the responses to indomethacin $(0.6 \mathrm{mg} / \mathrm{kg}$, i.v. $)$ while imidazole was infused ( 2.0 and $4.0 \mathrm{mg} / \mathrm{kg} / \mathrm{min}$, i.v.). All values are expressed as means \pm S.E. The number of experiments is in parentheses. The asterisk signifies that results are significantly different from control $(P<0.001)$ and the accompanying imidazole response $(P<0.001)$

nor $\mathrm{PGG}_{2}$ were effective in reversing indomethacin-induced constriction of the ductus arteriosus. Dilatation by the various PGs of the indomethacin-constricted ductus arteriosus was unaccompanied by significant changes in heart rate or systemic arterial pressures, but was associated invariably with a reduction in pulmonary arterial pressure levels to control values.

The responses to varying doses of $\mathrm{PGI}_{2}$ were of particular interest. It was found that only relatively high doses of $\mathrm{PGI}_{2}$ reversed indomethacin-induced ductal constriction (Table 1). Low doses of $\mathbf{P G I}_{2}$ did not influence the calibre of the ductus arteriosus. This finding was independent of the path of injection, e.g., directly into the superior vena cava and, hence, into the lumen of the ductus arteriosus, or through a catheter implanted chronically in the left atrium, which would be expected to deliver $\mathrm{PGI}_{2}$ to the vaso-vasora of the ductus. Low doses of $\mathrm{PGI}_{2}$, although not influencing the calibre of the indomethacin-constricted ductus arteriosus, had profound effects on pulmonary and systemic arterial pressures. At a mean dose of $\mathrm{PGI}_{2}$ of $75 \pm 7 \mu \mathrm{g} / \mathrm{kg}$, main pulmonary arterial pressure fell from $87 \pm 6 / 51 \pm 3$ torr to $69 \pm$ $5 / 42 \pm 4(P<0.001$ systolic $/ P<0.003$ diastolic $)$, whereas aortic pressure fell from $75 \pm 3 / 49 \pm 3$ torr to $68 \pm 3 / 42 \pm 3(P<0.02$ systolic $/ P<0.003$ diastolic). In this experiment prostacyclin appears to have caused significant pulmonary and systemic vasodilatation whereas not reversing indomethacin-mediated ductal constriction.

\section{AUTONOMIC NERVOUS SYSTEM MEDIATORS AND BLOCKERS}

In this group of experiments, 17 studies were performed from 1-29 days postoperatively on six animals, with gestational ages ranging between 120-146 days. Autonomic blocking agents were administered in doses that were shown to inhibit the effects of their agonists (Table 1). Although significant alterations in blood pressure and heart rate were observed in this series of experiments, with the possible exception of acetylcholine, no alterations occurred in the cross-sectional area of the fetal ductus arteriosus. Acetylcholine at high dose $(1 \mu \mathrm{g} / \mathrm{kg} / \mathrm{min})$ caused substantial systemic and pulmonary hypotension, which was associated with a $13 \pm 7 \%$ decrease in the cross-sectional area of the ductus arteriosus. This hemodynamic effect was reversed by atropine, but not $\mathrm{PGE}_{1}$. Atropine alone raised the heart rate an average of 11 
$\pm 3 \%$ without significantly altering pulmonary or systemic pressures and was ineffective in reversing the indomethacin-induced constriction of the ductus arteriosus.

In the doses employed (Table 1), norepinephrine raised heart rate $5-26 \%$ and pulmonary and systemic arterial pressures $4-22 \%$; changes unaccompanied by alterations in dimensions of the ductus arteriosus. Indomethacin constriction of the ductus arteriosus was not influenced by pretreatment of the fetus with norepinephrine

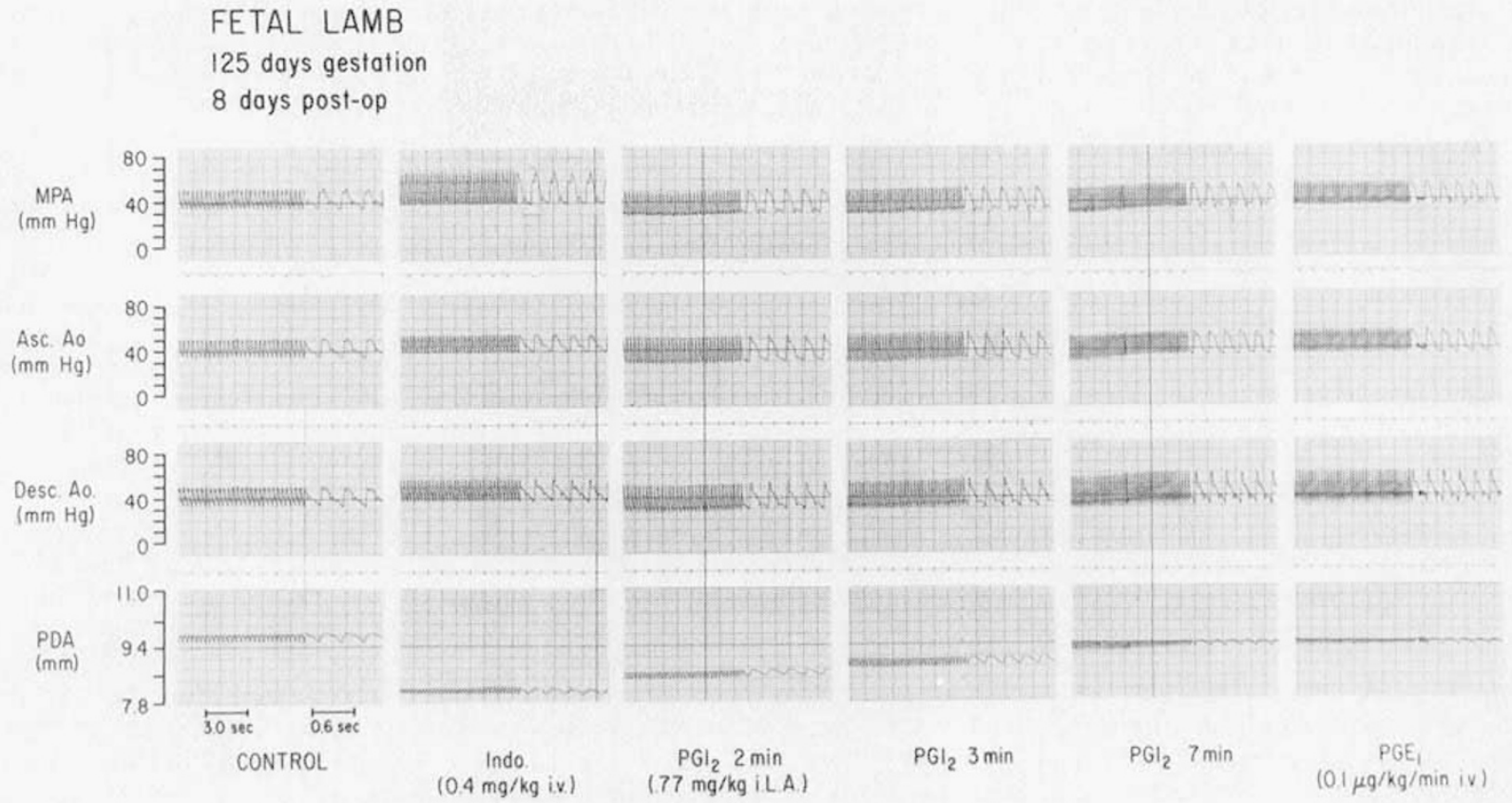

Fig. 5. Prostacyclin $\left(\mathrm{PGI}_{2}\right)$ infusion into the left atrium (L.A.) reverses indomethacin (indo.) induced constriction of the ductus arteriosus in a 125 day fetal lamb studied 8 days after instrumentation. Note that $P_{1} E_{1}$ produced no further dilation of patent ductus arteriosus when compared to $P G I_{2}$. MPA, main pulmonary artery pressure; Asc. Ao., ascending aorta pressure; Desc. Ao., descending aorta pressure; PDA, external diameter, (mm).
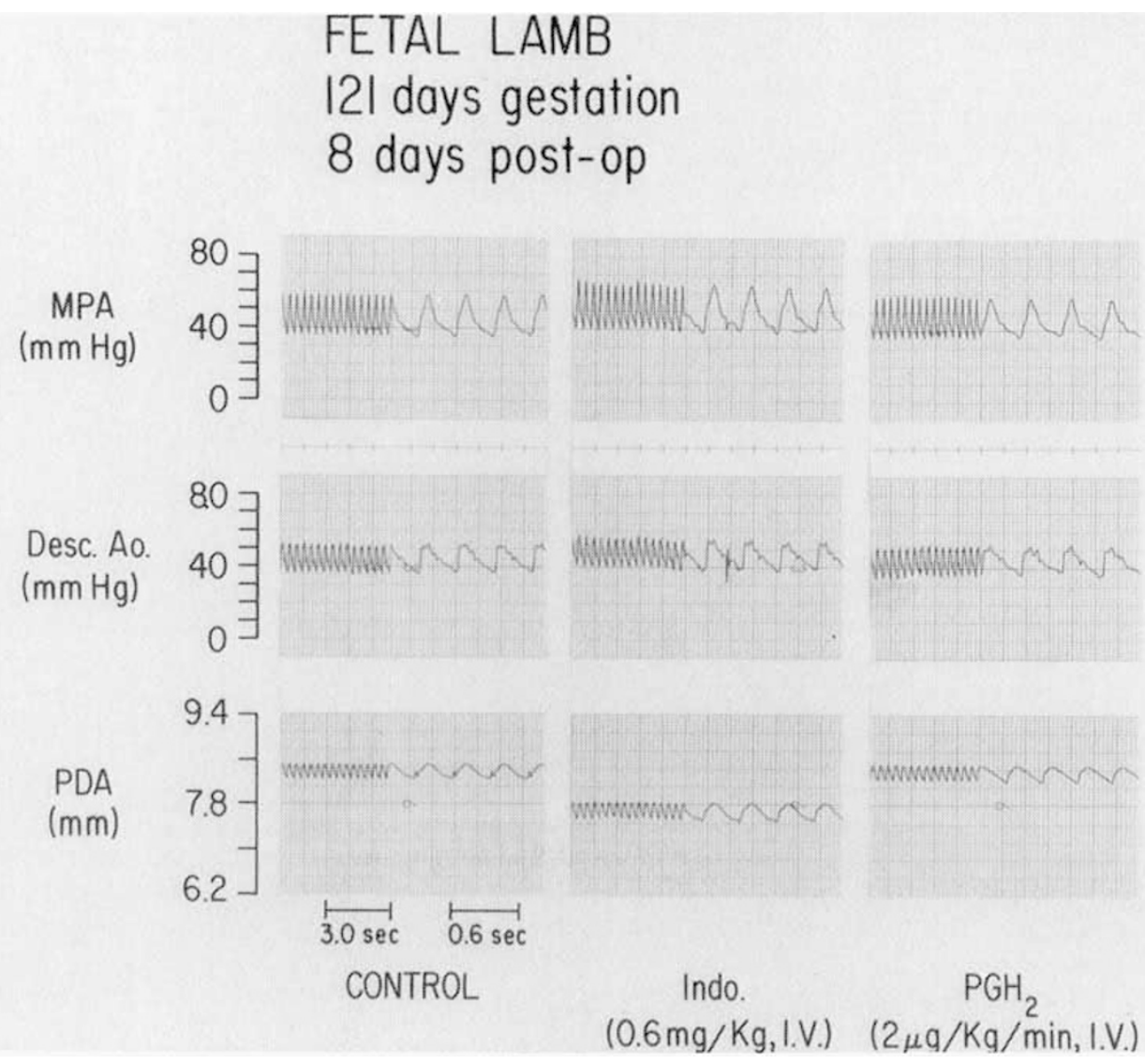

Fig. 6. Prostaglandin endoperoxide $\left(\mathrm{PGH}_{2}\right)$ reversal of indomethacin (indo.) constriction of the ductus arteriosus in a 121 -day fetal lamb 8 days after instrumentation. Abbreviations as in Figure 5. 
or reversed by subsequent infusion of the adrenergic neurotransmitter. Beta-adrenergic blockade decreased the fetal heart rate 10 and $16 \%$ without altering pulmonary or systemic pressures. Propranolol did not influence either the subsequent $\mathrm{PGE}_{1}$-mediated constriction of the ductus arteriosus by indomethacin or reversal of the constriction. Methoxamine raised pulmonary and systemic arterial pressures ( $19 \pm 6 \%$ and $25 \pm 9 \%$, respectively) over a 20 $30 \mathrm{~min}$ period, during which time heart rate fell an average of 28 $\pm 11 \%$. When phentolamine was injected into the fetal circulation during methoxamine infusion, heart rate invariably increased and arterial pressure fell to control levels. The diameter of the ductus arteriosus was unchanged by these stimuli and neither drug influenced the constrictor response of the ductus arteriosus to indomethacin.

\section{ANGIOTENSIN I AND II, CONVERTING ENZYME BLOCKER, SEROTONIN, METHYSERGIDE}

Sixteen experiments were performed on nine animals with gestational ages ranging from 115-134 days, who had recovered 2 19 days after chronic instrumentation. Angiotensin I and II increased systemic blood pressures 4 and $11 \%$, respectively, with no significant alteration in pulmonary arterial systolic pressure or heart rate. Converting enzyme blocker (SQ20881) did not directly influence heart rate or blood pressures. None of these agents influenced the dimensions of the ductus arteriosus directly or interfered with the indomethacin-induced constriction of the ductus arteriosus.

The infusion of serotonin or administration of methysergide did not affect the ductus arteriosus directly or after indomethacin. Serotonin raised the heart rate an average of $27 \%(P<0.05)$ and both pulmonary and systemic arterial systolic pressures (17 and $22 \%$, respectively, $P<0.05$ ). These hemodynamic responses were blocked by methysergide.

\section{AMINOPHYLLINE, ADENOSINE, AND DIBUTYRL CYCLIC AMP}

Eight experiments were performed on seven animals with gestational ages ranging from 113-116 days, who had recovered postoperatively 5-19 days. None of these agents caused a significant-change in the dimensions of the ductus arteriosus, nor did they inhibit the ability of indomethacin to constrict the ductus arteriosus. Adenosine, but not aminophylline or dibutyrl cyclic AMP, altered the heart rate response significantly. After adenosine, heart rate decreased from $182 \pm 27 / \mathrm{min}$ to $128 \pm 28 / \mathrm{min}$, which was accompanied by $4-6 \mathrm{mmHg}$ reductions in main pulmonary arterial and aortic systolic pressures. Neither aminophylline nor dibutyrl cyclic AMP altered systemic or pulmonary blood pressures.

\section{DISCUSSION}

Attention was called 41 years ago to the unique oxygen sensitivity of the ductus arteriosus (23). Since then, many additional mechanisms have been proposed as the stimulants for muscular closure of the ductus arteriosus at birth (1-3, 13, 25-33). Prominent among these were autonomic and neural factors and the kinins (19). Most recently, evidence has accumulated supporting the notion that control of ductus arteriosus patency and closure is mediated through prostaglandins. Several reviews have been published that summarize the background data implicating alterations in the prostaglandin milieu in the modulation of the calibre of the ductus arteriosus $(12,16)$.

Sympathetic and parasympathetic innervation of the ductus arteriosus has been demonstrated in several species $(2,32)$, although studies of isolated patent ductus arteriosus strips have demonstrated that the constrictor response to oxygen is not effected by stimulation with, or blockade of, the adrenergic and cholinergic neurotransmitters $(30,31)$. Other in vitro or in vivo investigations concerned with the influence of the autonomic nervous system in modulating the smooth muscle tone of the ductus arteriosus are inconclusive, or contradictory (1-3, 25-27,
33). In the present study, despite hemodynamic perturbations, no changes were observed in the dimensions of the fetal ductus arteriosus upon administration directly of norepinephrine, propranolol, phentolamine, or methoxamine; moreover, none of these adrenergic drugs altered the responsiveness of the ductus arteriosus to prostaglandins or inhibition of prostaglandin synthesis. Although the latter comment may be applied to atropine, acetylcholine administration resulted in a slight, direct reduction in the cross-sectional area of the fetal ductus arteriosus while concurrently lowering pulmonary and systemic blood pressures. The effect of acetylcholine was reversed by atropine, but not $\mathrm{PGE}_{\mathrm{I}}$. It must remain conjectural whether or not the cholinergic constriction of the ductus arteriosus was the result of an hydrostatic influence of hypotension, or the direct effect of the parasympathetic neurotransmitter.

Renovascular and tryptaminergic vasoactive agents did not appear to affect the ductus arteriosus or its responses to altering the prostaglandin milieu. Neither infusion of angiotensin I or angiotensin II, nor blockade of conversion of angiotensin I to II with SQ 20881 influenced the dimensions of the ductus directly, or after the fetal vascular channel was constricted with indomethacin. Similarly, serotonin and methysergide had no influence on ductal calibre.

Because speculation exists that cyclic nucleotides might function as a link between hormonal stimulation and contractility in vascular smooth muscle, evidence was sought but not found for a physiologic role for cyclic nucleotides in the regulation of contractility of the ductus arteriosus. The phosphodiesterase inhibitor theophylline, and dibutyrl cyclic AMP did not influence the dimensions of the ductus arteriosus directly, nor did their administration alter the ability of indomethacin to constrict the ductus arteriosus. These same findings were observed with the cyclic nucleotide metabolite, adenosine. These experiments suggest, but do not prove, that cyclic nucleotides do not play a physiologic role in modulating the smooth muscle tone of the ductus arteriosus.

The major finding of the present experiments was the exquisite sensitivity of the ductus arteriosus to perturbations in the prostaglandin environment. The ductus arteriosus appeared to be dilated maximally in utero because direct infusion of prostaglandins did not cause further dilatation of the vascular channel. Single intravenous doses of as little as $0.01 \mathrm{mg} / \mathrm{kg}$ of the prostaglandin synthetase inhibitor, indomethacin, caused significant constriction of the ductus arteriosus. $\mathrm{PGE}_{1}, \mathrm{PGE}_{2}, \mathrm{PGH}_{2}$, and $\mathrm{PGI}_{2}$ were all capable of reversing the constrictor response to indomethacin in the absence of any alterations in fetal arterial $\mathrm{pH}, \mathrm{Po}_{2}$, or $\mathrm{PCO}_{2}$. In contrast to isolated tissue studies $(6,7)$ indomethacin's constrictor response did not appear to be influenced by the age of the fetus because animals at 95 days ( 0.65 gestation) showed reductions in ductus arteriosus cross-sectional area to varying doses of the PG synthesis inhibitor comparable to that observed in animals close to term. $\mathrm{PGI}_{2}$ was found to be less potent than $\mathrm{PGE}_{1}$ in reversing indomethacin-mediated ductal closure. Because $\mathrm{PGI}_{2}$ is not metabolized as rapidly as $\mathrm{PGE}_{1}$ it might be expected to have a longer half-life in vivo, which could offset differences at the receptor level. We would, therefore, conclude that ductal prostaglandin receptors respond more readily to $\mathrm{PGE}_{2}$ than to $\mathrm{PGI}_{2}$. One alternate explanation is that $\mathrm{PGE}_{1}$, being slightly less polar than $\mathrm{PGI}_{2}$, may gain access more readily to ductal receptors. It should be noted that $\mathrm{PGE}_{1}$ would not be expected to occur in significant amounts in mammalian organisms; thus, $\mathrm{PGE}_{2}$ and $\mathrm{PGI}_{2}$ may have greater physiologic significance.

These findings are generally compatible with studies of isolated fetal lamb ductus arteriosus, which suggest that $\mathrm{PGE}_{2}$ is the most potent ductus arteriosus relaxing agent known thus far $(4,11,28)$. It has been suggested that $\mathrm{PGI}_{2}$ per se only contributes to ductus patency by supplementing the $\mathrm{PGE}_{2}$ action on muscle cells, and by preventing platelet adhesions on the luminal surface (12). Coceani and Olley (12) have pointed out that 6 keto $\mathrm{PGE}_{1}$ is a very potent ductus arteriosus relaxing agent, and it should be recognized that $\mathrm{PGI}_{2}$ may indeed have a more central function in controlling ductus arteriosus contractility if future investigations demonstrate the presence, in ductus arteriosus tissue, of an enzyme 
system for the conversion of the $\mathrm{PGI}_{2}$ metabolite, 6 keto $\mathrm{PGF}_{1}$ to 6 keto $\mathrm{PGE}_{1}$.

Our results would argue that both a locally generated and a circulating component may be involved in ductal patency and closure. The dilatory effects of $\mathrm{PGE}_{2}$ and $\mathrm{PGI}_{2}$ - the former exhibiting the ability to act as a circulating hormone - appear to be important in ductal patency. Differences in endogenous prostaglandin synthesis may be expected to modify the action(s) of circulating influences. Constriction of the ductus would appear to be a result of an active process which is unknown at this time. In this regard it is of interest that imidazole is a potent inhibitor of thromboxane synthetase. The effect of imidazole in reversing indomethacin-mediated closure may relate to this activity; however, further studies are needed to resolve this question.

\section{REFERENCES AND NOTES}

1. Assali, N. S., Morris, J. A., Smith, R. W., and Manson, W. A.: Studies on ductus arteriosus circulation. Circ. Res., 13: 478 (1963).

2. Boreus, L. O., Malmfors, T., McMurphy, D. M., and Olson, L.: Demonstration of adrenergic receptor function and innervation in the ductus arteriosus of the human fetus. Acta Physiol. Scand., 77: 316 (1969).

3. Cassels, D. E. and Moore, R. Y.: Sympathetic innervation of the ductus arteriosus in relation to patency. Chest, 63: 727 (1973).

4. Clyman, R. I., Mauray, F., Roman, C., et al: $\mathrm{PGE}_{2}$ is a more potent vasodilator of the lamb ductus arteriosus than either $\mathrm{PGI}_{2}$ or 6-keto-PGF ${ }_{1 \alpha}$. Prostaglandins, 16: 259 (1978).

5. Clyman, R. I., Wong, L., Heymann, M. A., and Rudolph, A. M.: Responsiveness of the lamb ductus arteriosus to prostaglandins and their metabolites. Prostaglandins, 15: 325 (1978)

6. Clyman, R. I., Mauray, F., Rudolph, A. M., et al: Age-dependent sensitivity of the lamb ductus arteriosus to indomethacin and prostaglandins. J. Pediatr., 96 : 94 (1980).

7. Clyman, R. I.: Ontogeny of the ductus arteriosus response to prostaglandins and inhibitors of their synthesis. Semin. Perinatol., 4: 115 (1980).

8. Coceani, F. and Olley, P. M.: The response of the ductus arteriosus to prostaglandins. Can. J. Physiol. Pharmacol., 5I: 220 (1973).

9. Coceani, F., Olley, P. M., Bishai, I., Bodach, E., and White, E. P.: Significance of the prostaglandin system to the control of muscle tone of the ductus arteriosus. In: Coceani, F. and Olley, P. M. (Eds.): Adv. Prostaglandin Thromboxane Res. (vol. 4). p. 325. (Raven Press, New York 1978)

10. Coceani, F., Bishai, I., White, E. et al: Actions of prostaglandins, endoperoxides and thromboxanes on the lamb ductus arteriosus. Am. J. Physiol., 234: H117 (1978).

11. Coceani, F., Bodach, E., White, E., et al: Prostaglandin I., is less relaxant than prostaglandin $\mathrm{E}_{2}$ on the lamb ductus arteriosus. Prostaglandins, 15: 551 (1978)

12. Coceani, F. and Olley, P. M.: Role of prostaglandins, prostacyclin and thromboxanes in the control of prenatal patency and postnatal closure of the ductus arteriosus. Semin. Perinatol., 4: 109 (1980).

13. Elliot, R. B. and Starling, M. D.: The effects of prostaglandin $F_{2 \alpha}$ in the closure of the ductus arteriosus. Prostaglandins, 5: 399 (1972)

14. Friedman, W. F., Hirschklau, M. J., Printz, M. P., et al: Pharmacologic closure of patent ductus arteriosus in the premature infant. N. Engl. J. Med., 295: 526 (1976).

15. Friedman, W. F., Fitzpatrick, K. M., Merritt, T. A., and Feldman, B. H.: The patent ductus arteriosus. Clin. Perinatol., 5: 411 (1978).
16. Friedman, W. F., Molony, D. A., and Kirkpatrick, S. E.: Prostaglandins: physiological and clinical correlations. In: Advances in Pediatrics, p. 151 (Yearbook Medical Publications, Inc., Chicago, 1978).

17. Friedman, W. F., Printz, M. P., and Kirkpatrick, S. E.: Blockers of prostaglandin synthesis: a novel therapy in the management of the premature human infant with patent ductus arteriosus. In: Coceani, F. and Olley, P. M. (Eds.): Advances in Prostaglandins and Thromboxanes, (Vol. 4). pp. 373-382. (Raven Press, New York 1978).

18. Friedman, W. F., Printz, M. P., Skidgel, R. A., Benson, L. N., and Zednikova, M. Prostaglandins and the ductus arteriosus. In: Oates, J A (Ed ) Prostaglandins and the Cardiovascular System. Samuelsson, B. and Paoletti, R. (Eds.). Advances in Prostaglandin and Thromboxane Research. (Raven Press, New York 19 ).

19. Heymann, M, A. and Rudolph, A. M.: Control of the ductus arteriosus. Physiol. Rev., 55: 61 (1975).

20. Heymann, M. A. and Rudolph, A. M.: Effects of acetysalicylic acid on the ductus arteriosus and circulation in fetal lambs in utero. Circ. Res., 38: 418 (1976).

21. Heymann, M. A. and Rudolph, A. M.: Ductus arteriosus dilatation by prostaglandin $E_{1}$ in infants with pulmonary atresia. Pediatrics, 59: 325 (1977).

22. Hoskins, E. J., Kirkpatrick, S. E., and Friedman, W. F,: Pulmonary-aortic pressure gradients as an index of the caliber of the patent ductus arteriosus. Am. J. Obstet. Gynecol., 135: 543 (1979).

23. Kenedy, J. A. and Clark, S. L.: Observations on the ductus arteriosus of the guinea pig in relation to its method of closure. Anat. Rec., 79: 349 (1941).

24. Kirkpatrick, S. E., Covell, J. W., and Friedman, W. F.: A new technique for the continuous assessment of fetal and neonatal cardiac performance. Am. J. Obstet. Gynecol., 116: 963 (1973).

25. Knight, D. H., Patterson, D. F., and Melbin, J.: Constriction of the fetal ductus arteriosus induced by oxygen, acetylcholine, and norepinephrine in normal dogs and those genetically predisposed to persistent patency. Circulation, 47: 127 (1973).

26. Kovalcik, V.: The response of the isolated ductus arteriosus to oxygen and anoxia. J. Physiol., 169: 185 (1953).

27. Kovalcik, V. and Kriska, M. and Dolezel, S.: The problem of adrenergic innervation of the ductus arteriosus in the guinea-pig foetus and its role in the mechanism of constriction. Physiol. Bohemoslov, 18: 401 (1969).

28. Kuehl, F. A.: Prostaglandins, cyclic nucleotides and cell function. Prostaglandins, 5: 325 (1974).

29. McMurphy, D. M. and Boreus, L. O.: Studies on the pharmacology of the perfused human fetal ductus arteriosus. Am. J. Obstet. Gynecol., 109: 937 (1971)

30. McMurphy, D. M., Heymann, M. A., Rudolph, A. M., et al: Developmental changes in constriction of the ductus arteriosus: responses to oxygen and vasoactive substances in the isolated ductus arteriosus of the fetal lamb. Pediatr. Res., 6: 231 (1972).

31. Reis, R. L. and Anderson, R. P.: Constriction of the ductus arteriosus: experimental observations in the newborn lamb. J. Surg. Res., 4: 356 (1964).

32. Silva, D. G. and Ikeda, M.: Ultrastructural and acetylcholinesterase studies on the innervation of the ductus arteriosus, pulmonary trunk and aorta of the fetal lamb. J. Uitrastruct. Res., 34: 358 (1971).

33. Smith, R. W., Morris, J. A., and Assali, N. S.: Effects of chemical mediators on the pulmonary and ductus arteriosus circulation in the fetal lamb. Am. J. Obstet. Gynecol., 89: 252 (1964)

34. Requests for reprints should be addressed to: Dr. William F. Friedman, Professor and Chairman, Department of Pediatrics, 22-412 MDCC, UCLA Center for the Health Sciences, Los Angeles, CA 90024.

35. This research was supported by Grants HL25476, HL15808 and HL18259 from the National Heart, Lung and Blood Institute of the National Institutes of Health.

36. Received for publication June 21, 1982

37. Accepted for publication November 3, 1982 